\title{
KORELASI KONSENTRASI COCOA BUTTER SUBSTITUTE TERHADAP KARAKTERIKSTIK WHITE CHOCOLATE YANG DIPERKAYA BLACK TEA POWDER (Camellia sinensis)
}

\author{
Yusep Ikrawan \\ Dede Zainal Arief \\ Early Lirayani
}

\begin{abstract}
Program Studi Teknologi Pangan Fakultas Teknik Universitas Pasundan, Jl. Dr. Setiabudhi No. 193, Bandung, 40153, Indonesia.

E-mail : yusepikrawan@unpas.ac.id
\end{abstract}

\begin{abstract}
Abstrak
Tujuan penelitian ini adalah untuk mengetahui korelasi substitusi cocoa butter (CBS) dengan penambahan serbuk teh hitam terhadap karakteristik fisik, kimia dan organoleptik, dan untuk mengetahui kadar asam palmitat pada produk coklat putih akibat penambahan katekin pada bubuk teh hitam. Rancangan penelitian yang digunakan adalah metode regresi linier sederhana, dimana variabel independen menyatakan konsentrasi substitusi cocoa butter adalah 38\%, 40\%, dan $42 \%$ dengan variabel terikat menyatakan ketegasan dan titik lebur. Desain analisis dilakukan untuk menentukan hubungan antara variabel bebas dan variabel terikat dengan menghitung korelasi antara dua variabel (CBS untuk titik leleh dan titik leleh) ke respon yang diukur. Respn variabel organoleptik meliputi warna, rasa, rasa, tekstur, dan aftertaste. Analisis kimia yang dilakukan adalah kadar lemak total, kadar asam lemak, kadar theaflavin, dan kadar katekin. Analisis fisik dilakukan pada titik leleh dan kekerasan cokelat. Hasil penelitian menunjukkan bahwa kandungan substitusi mentega coklat berkorelasi positif dengan serbuk teh hitam terhadap karakteristik titik leleh, tetapi berkorelasi negatif dengan karakteristik kekerasan coklat putih.
\end{abstract}

\begin{abstract}
The purpose of this research is to know the correlation of cocoa butter substitute (CBS) with the addition of black tea powder to physical, chemical and organoleptic characteristics, and to know the level of palmitic acid content in white chocolate product due to the addition of catechin on black tea powder.The research design used is simple linear regression method, where the independent variable states cocoa butter substitute concentration is $38 \%$, $40 \%$, and $42 \%$ with dependent variable expressing firmness and melting point. The design of the analysis is conducted to determine the relationship between the independent variable and the dependent variable by calculating the correlation between the two variables (CBS to frimness and melting point) to the measured response. Organoleptic response variables include color, flavor, taste, texture, and aftertaste. Chemical analysis that conduct were total fat content, fatty acid levels, theaflavin levels, and catechin levels. Physical analysis conducted on the melting point and hardness of chocolate.The results showed that cocoa butter substitute content was positively correlated with black tea powder to melting point characteristics, but negatively correlated to the characteristic of hardness of white chocolate.
\end{abstract}

Key Word: White Chocolate, Cocoa Butter Substitute, Black Tea Powder, Correlation

\section{Pendahuluan}

Cokelat adalah olahan yang dihasilkan dari bahan baku yaitu biji dan lemak kakao. Cokelat merupakan kategori makanan yang mudah dicerna oleh tubuh dan mengandung banyak vitamin seperti vitamin A1, B1, B2, C, D, dan E serta beberapa mineral seperti fosfor, magnesium, zat besi, zink, dan juga tembaga (Spillane, 1995 dalam Nabila, 2017).

Produsen cokelat pada umumnya memproduksi tiga macam cokelat jadi, yaitu cokelat pekat (dark chocolate), cokelat susu (milk chocolate), dan cokelat putih (white chocolate). Ketiga macam cokelat ini dibedakan berdasarkan komposisinya, yaitu dari kandungan cokelat, gula, serta bahan tambahan lain (Brown, 2010 dalam Nabila, 2017). Selain itu, juga terdapat cokelat jenis couverture yang merupakan cokelat premium yang sering digunakan oleh para profesional di industri untuk membuat pastry ataupun untuk membuat kue (Atkinson, Banks, France, \& Mc Fadden, 2010).

White chocolate atau cokelat putih memiliki komposisi yang hampir sama dengan milk chocolate namun tidak mengandung cokelat padat melainkan menggunakan lemak cokelat (cocoa butter) dengan gula dan susu bubuk. Secara teknis, cokelat putih tidak dapat dikategorikan sebagai cokelat karena tidak mengandung kakao ataupun cokelat padat (Brown, 2010 dalam Nabila, 2017).

Cokelat putih paling tidak mengandung 20\% minyak cokelat, $14 \%$ susu, sekitar $55 \%$ gula dan bahan-bahan lainnya (Brown, 2010 dalam Nabila, 
2017). Cokelat ini biasanya dijual agar bisa menghasilkan berbagai macam warna untuk permen cokelat ataupun kue (Atkinson, Banks, Frances \& Mc fadden, 2010).

Pembuatan white chocolate secara umum menggunakan cocoa butter, namun dalam pelaksanaannya cocoa butter memiliki harga yang relatif mahal. Salah satu pengganti cocoa butter dalam pembuatan white chocolate adalah minyak nabati seperti Cocoa Butter Substitute. Menurut Elisabeth dalam Nabila (2017), Cocoa Butter Substitute lebih ditujukan pada produk lemak yang menggunakan minyak non laurat dari inti sawit. Penggunaan Cocoa Butter Substitute (CBS) dalam pembuatan produk cokelat dapat menghasilkan kualitas produk cokelat hampir sama dengan cokelat menggunakan cocoa butter.

Hasil penelitian Nabila (2017) menyatakan, Produk white chocolate menggunakan variasi susu skim dan tepung kedelai dengan bahan utama cocoa butter substitute menyebabkan kadar lemak dan protein meningkat. Hal ini dapat menjadi diversifikasi bahwa produk white chocolate dapat divariasikan dengan penambahan jahe, buah-buahan, kacang-kacangan, black tea, dan lain-lain.

Teh hitam adalah sejenis teh yang dalam pengolahannya melalui proses fermentasi secara penuh. Fermentasi tidak menggunakan mikroba sebagai sumber enzim, tetapi menggunakan enzim polyphenol oksidase yang terdapat didalam daun teh itu sendiri. Teh hitam memiliki kandungan antioksidan salah satunya adalah catechins. Catechins diketahui bisa meningkatkan metabolisme, membakar lemak dengan cepat, dan mengurangi tingkat kolesterol buruk. (Hartoyo, 2003 dalam Ekawati, 2011).

Cocoa Butter Substitute memiliki kandungan asam lemak, diantaranya miristat, palmitat, stearat, oleat, dan linoleat. Asam palmitat juga terdapat dalam lemak sapi. Asupan dalam jumlah banyak, secara signifikan tidak hanya meningkatkan kadar kolestrol Low Density Lipoprotein (LDL), akan tetapi sekaligus meningkatkan kadar kolesterol High Density Lipoprotein (HDL) darah. Dengan demikian secara otomatis meningkatkan kadar kolesterol total darah (yang jumlahnya merupakan paduan kolesterol HDL dan LDL), serta memperkecil rasio kolesterol total HDL (Tuminah, 2009). Oleh karena itu, asam palmitat diupayakan lebih sedikit. Senyawa yang diduga dapat menguranginya yaitu bersifat oksidator, salah satunya adalah katekin yang terdapat dalam black tea powder. Diharapkan dengan substitusi ini akan berkorelasi terhadap produk white chocolate.

Penelitian ini diharapkan dapat menjadi sebuah produk pangan fungsional, dimana pembuatan white chocolate dengan menggunakan cocoa butter substitute sebagai pengganti cocoa butter yang diperkaya dengan sumber antioksidan yang terdapat dalam black tea powder.
Tujuan dari penelitian ini adalah untuk mengetahui korelasi Cocoa Butter Substitute dengan penambahan black tea powder terhadap karakteristik white chocolate, serta untuk mengetahui kadar asam palmitat yang terkandung dalam produk white chocolate karena adanya penambahan katekin pada black tea powder.

Penelitian ini diharapkan dapat memperoleh manfaat untuk meningkatkan sifat fungsional dari Cocoa Butter Substitute (CBS) dan black tea powder sebagai sumber senyawa aktif yang baik serta untuk pengembangan teknologi pengolahan produk pangan.

\section{Metode Penelitian Rancangan Percobaan}

Rancangan penelitian yang digunakan yaitu metode regresi linier sederhana, dimana sumbu $x$ (variabel bebas) menyatakan konsentrasi cocoa butter substitute dan sumbu y (variabel terikat) menyatakan kekerasan, dan titik leleh.

Metode percobaan untuk penelitian ini adalah sebagai berikut :

$$
\mathrm{Y}=\mathrm{a}+\mathrm{bx}
$$

Keterangan :

$\mathrm{Y}=$ Variabel Terikat

$\mathrm{x}=$ Variabel Bebas

$\mathrm{a}=$ Bilangan Konstan (intersep garis regresi)

$b=$ Koefisien Regresi (slope garis regresi)

Nilai a maupun nilai b dapat dihitung melalui rumus yang sederhana. Untuk memperoleh nilai a dapat digunakan rumus :

$$
\mathrm{a}=\frac{(\Sigma \mathrm{y})\left(\Sigma \mathrm{x}^{2}\right)-(\Sigma \mathrm{x})(\Sigma \mathrm{xy})}{\mathrm{n}\left(\Sigma \mathrm{x}^{2}\right)-(\Sigma \mathrm{x})^{2}}
$$

Sedangkan nilai $\mathrm{b}$ dapat dihitung menggunakan rumus:

$\mathrm{b}=\underline{\mathrm{n}(\Sigma \mathrm{xy})-(\Sigma \mathrm{x})(\Sigma \mathrm{y})}$

$$
\mathrm{n}\left(\Sigma \mathrm{x}^{2}\right)-(\Sigma \mathrm{x})^{2}
$$

(Sumber : Sudjana, 2005).

Denah layout penelitian dan pendataan variabel bebas serta terikat dapat dilihat di bawah ini.

Data analisis yang diperoleh, akan diakumulasi ke dalam kurva sebagai berikut :

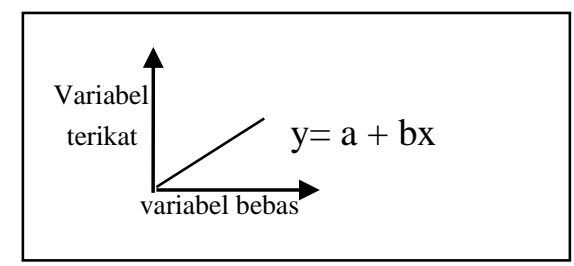

Gambar 1. Kurva Regresi Linier

\section{Rancangan Respon}

Rancangan respon yang dilakukan pada penelitian ini meliputi respon fisik, respon kimia, dan respon organoleptik.

Respon fisik yang dilakukan pada produk white chocolate yaitu penentuan titik leleh dengan menggunakan pipa kapiler, penentuan kekerasan dengan texture analyzer. 
Respon kimia yang dilakukan pada produk white chocolate adalah analisis kadar asam lemak dengan menggunakan Gas Chromatography dan analisis kadar katekin dan theaflavin.

Uji organoleptik yang dilakukan terhadap produk white chocolate adalah uji kesukaan atau panelis terhadap respon produk yang diuji dengan skala hedonik terhadap atribut warna, rasa, aroma, tekstur, dan after taste untuk menentukan sampel terpilih dengan panelis yang terdiri dari 30 orang.

\section{Hasil dan Pembahasan}

\section{Penelitian Utama}

Penelitian utama yang dilakukan bertujuan untuk mengetahui korelasi antara cocoa butter substitute terhadap karakteristik white chocolate dengan konsentrasi sebesar 38\%, 40\%, dan $42 \%$ yang diperkaya black tea powder.

Produk white chocolate yang dihasilkan dilakukan uji penerimaan secara organoleptik dengan metode hedonik yang bertujuan untuk mengetahui tingkat kesukaan konsumen terhadap produk dengan melibatkan 30 orang panelis. Parameter yang digunakan yaitu atribut warna, aroma, rasa, tekstur, dan after taste. Analisis selanjutnya yaitu karakteristik secara fisik dan kimia. Analisis kimia diantaranya penentuan kadar katekin dan theaflavin, lemak total, dan asam lemak yang terkandung dalam produk white chocolate. Analisis fisik diantaranya titik leleh dan kekerasan produk white chocolate.

\section{Respon Kimia}

\section{Kadar Lemak Total}

Analisis kadar lemak total metode ekstraksi soxhlet pada sampel white chocolate tanpa penambahan black tea powder bertujuan untuk mengetahui kadar lemak total yang terkandung pada produk white chocolate tersebut agar dapat digunakan sebagai pembanding dengan kadar lemak total yang terkandung dalam white chocolate yang ditambahkan black tea powder sehingga dapat diketahui korelasi antara lemak pada CBS dengan katekin pada black tea powder.

Tabel 1. Hasil Analisis Kadar Lemak Total

\begin{tabular}{|c|c|c|}
\hline $\begin{array}{c}\text { Jenis } \\
\text { Contoh }\end{array}$ & Hasil & $\begin{array}{c}\text { Metode } \\
\text { Pengujian }\end{array}$ \\
\hline $\begin{array}{c}\text { White } \\
\text { Chocolate } \\
\text { tanpa }\end{array}$ & & \\
Black Tea & & Ekstraksi \\
Powder & $44,8 \%$ & Soxhlet \\
\hline
\end{tabular}

Analisis lemak total dilakukan untuk mengetahui kadar lemak pada produk terpilih white chocolate, yaitu produk yang memiliki kadar CBS sebesar 38\%. Hasil analisis dapat dilihat pada tabel 2.
Tabel 2. Hasil Analisis Kadar Lemak Total

\begin{tabular}{|c|c|c|}
\hline $\begin{array}{c}\text { Jenis } \\
\text { Contoh }\end{array}$ & $\begin{array}{c}\text { Hasil } \\
\text { Pengujian/Pemeriksaan }\end{array}$ & $\begin{array}{c}\text { Metode } \\
\text { Pengujian }\end{array}$ \\
\hline $\begin{array}{c}\text { White } \\
\text { Chocolate } \\
\text { diperkaya }\end{array}$ & \\
Black Tea & & Ekstraksi \\
Powder & $43,4 \%$ & Soxhlet \\
\hline
\end{tabular}

Menurut Zieglender (2006) dalam Mayasari (2007), Migrasi lemak di dalam cokelat sangat dipengaruhi pada temperatur penyimpanan. Cokelat menjadi lebih lembut dengan suhu naik sehingga cokelat dapat dengan mudah menerima minyak dari bahan pengisi

Menurut Winarno (1990) dalam Permatasari (2016), lemak kakao yang digunakan sebagai bahan pencampur pembuatan produk cokelat memiliki sifat plastis yang artinya mudah dibentuk dan dicetak dan mengandung trigliserida yang padat dan sebagian yang cair. Bila suatu lemak didinginkan, hilangnya panas akan memperlambat gerakan molekul dalam lemak, sehingga jarak antar molekul menjadi lebih kecil.

Lemak yang tidak memiliki persamaan dengan lemak kakao tetapi dapat digunakan dengan baik apabila dicampurkan dalam jumlah kecil pada lemak kakao atau cokelat dapat disebut sebagai pengganti lemak kakao (cocoa butter substitute). Lemak ini dapat diproduksi dari minyak kelapa, kelapa inti sawit, serta minyak kacang (Minifie, 1989 dalam Noordiansyah, 2016).

Lemak (Lipid) adalah zat organik hidrofobik yang bersifat sukar larut dalam air. Namun lemak dapat larut dalam pelarut organik seperti kloroform, eter dan benzen. Unsur penyusun lemak antara lain adalah Karbon (C), Hidrogen (H), Oksigen (O), Fosfor (P) serta Nitrogen $(\mathrm{N})$. Molekul lemak terdiri dari empat bagian, yaitu satu molekul gliserol dan tiga molekul asam lemak. Asam lemak terdiri dari rantai Hidrokarbon $(\mathrm{CH})$ dan gugus Karboksil (-COOH). Molekul gliserol memiliki tiga gugus Hidroksil (-OH) dan tiap gugus hidroksil berinteraksi dengan gugus karboksil asam lemak. Lemak kakao merupakan lemak nabati yang sangat penting pada industri cokelat dan permen karena memiliki karakteristik fisik yang unik dari komposisi trigliserida (TG) yang tersusun terutama dari POS 55\%, POP 5\%, dan SOS 20\%, dan memiliki kisaran titik leleh sekitar $32-35^{\circ} \mathrm{C}$ (Martinez, et.al., 2006, Liu, et.al., 2007 dalam Noordiansyah, 2016).

\section{Kadar Asam Lemak Total}

Analisis kadar asam lemak pada sampel white chocolate tanpa penambahan black tea powder bertujuan untuk mengetahui total asam lemak yang terkandung pada white chocolate sehingga dapat dijadikan sebagai perbandingan dengan asam lemak yang terkandung dalam white chocolate yang ditambahkan black tea powder sehingga dapat 
diketahui korelasi antara asam lemak yang terkandung dengan katekin pada black tea powder.

Tabel 3. Hasil Analisis Kadar Asam Lemak Total

\begin{tabular}{|c|c|c|}
\hline No. & Jenis Asam Lemak & $\begin{array}{c}\text { Total Asam Lemak } \\
(\%)\end{array}$ \\
\hline 1. & Methyl Caprate & 4,07 \\
\hline 2. & 2-Dodecen-1-al & 0,62 \\
\hline 3. & Methyl Laurate & 51,85 \\
\hline 4. & Methyl Myristate & 12,29 \\
\hline 5. & Methyl Palmitate & 12,92 \\
\hline 6. & Methyl Linoleat & 3,68 \\
\hline 7. & Methyl Octadecenoat & 5,23 \\
\hline 8. & Methyl Stearate & 9,34 \\
\hline
\end{tabular}

Hasil penelitian utama analisis kualitatif asam lemak total metode Gas Chromatography Mass Spectrometry (GC-MS) dengan sampel terpilih yaitu kadar CBS sebesar 38\% dapat dilihat pada tabel 4.

Tabel 4. Hasil Analisis Asam Lemak Total Metode GC-MS

\begin{tabular}{|c|c|c|}
\hline No. & Jenis Asam Lemak & $\begin{array}{c}\text { Total Asam Lemak } \\
(\%)\end{array}$ \\
\hline 1. & Methyl Caprate & 3,00 \\
\hline 2. & 2-Dodecen-1-al & 344 \\
\hline 3. & Methyl Laurate & 38,64 \\
\hline 4. & Methyl Myristate & 9,36 \\
\hline 5. & Methyl Palmitate & 17,70 \\
\hline 6. & Methyl Linoleat & 4,24 \\
\hline 7. & Methyl Octadecenoat & 6,99 \\
\hline 8. & Methyl Stearate & 10,50 \\
\hline 9. & Phthalate & 3,03 \\
\hline
\end{tabular}

Hasil uji analisis asam lemak secara kualitatif metode GC-MS menunjukkan bahwa produk white chocolate yang diperkaya black tea powder mengandung asam palmitat lebih tinggi dibandingkan dengan control. Hal tersebut terlihat dari hasil yang keluar dari peak yang terdeteksi dengan alat GC-MS dengan luas area peak bervariasi.

Hasil penelitian Fakmi (2016) menyatakan bahwa, senyawa yang terdeteksi oleh alat GC-MS hanya bisa melihat kandungan senyawa kompleks yang terdapat pada suatu bahan dengan menggunakan perbedaan titik didih tanpa bisa mengetahui kadar asam lemak yang terkandung.

Menurut Ketaren (1986) dalam Fakhmi (2016), Asam lemak bebas yang terbentuk dalam produk makanan terdapat dalam jumlah kecil dan sebagian besar terikat dalam bentuk ester trigliserida. Reaksi hidrolisis dan oksidasi lemak akan mengakibatkan ketengikan yang menghasilkan flavor dan bau tengik pada makanan mengandung lemak.

Asam lemak merupakan kelompok bahan alam yang sangat kompleks untuk dilakukan analisis langsung. Hingga saat ini tidak ada satu metode yang sederhana untuk mengidentifikasi asam lemak. Kromatografi gas dapat dipakai untuk melakukan analisis asam lemak pada minyak dalam bentuk metil esternya. Dalam analisis ini diperlukan beberapa teknik yang dapat menampilkan pemisahan metil ester penyusun minyak dalam kolom kromatografi dengan baik. Senyawa metil ester dari asam lemak suatu minyak mempunyai perbedaan titik didih yang kecil sehingga pemisahan beberapa metil ester pada suhu yang konstan akan mengalami kesulitan. Oleh sebab itu, diperlukan teknik suhu terprogram untuk analisis metil ester asam lemak dari minyak (Anwar, 1996 dalam Fakhmi, 2016).

Salah satu syarat suatu senyawa dapat dianalisis dengan GC-MS adalah senyawa tersebut harus bersifat mudah menguap (volatil). Pemisahan yang terjadi dapat disebabkan oleh beberapa titik didih suatu senyawa dan interaksi senyawa tersebut dengan fase diam dan kolom. Suatu asam lemak rantai panjang mempunyai titik didih yang tinggi karena mempunyai gugus karboksilat yang menyebabkan terjadinya ikatan hidrogen dan peningkatan jumlah rantai hidrokarbon akan menyebabkan peningkatan titik didihnya (Fessenden, 1999).

\section{Kadar Katekin}

Analisis kadar katekin yang dilakukan di penelitian pendahuluan bertujuan untuk mengetahui kadar katekin yang terkandung dalam black tea powder. Hasil dari analisis katekin ini akan digunakan untuk mengetahui perbandingan kadar katekin sebelum dan sesudah dijadikan produk white chocolate sehingga dapat diketahui korelasi antara katekin dengan asam palmitat pada produk white chocolate.

Tabel 5. Hasil Analisis Kadar Katekin

\begin{tabular}{|c|c|c|}
\hline $\begin{array}{c}\text { Jenis } \\
\text { Contoh }\end{array}$ & $\begin{array}{c}\text { Hasil } \\
\text { Pengujian/Pemeriksaan }\end{array}$ & Metode Pengujian \\
\hline $\begin{array}{c}\text { Black Tea } \\
\text { Powder }\end{array}$ & $0,98 \%$ & Spektrofotometri \\
\hline
\end{tabular}

Hasil penelitian utama analisis kualitatif asam lemak total metode Gas Chromatography Mass Spectrometry (GC-MS) dengan sampel terpilih yaitu kadar CBS sebesar 38\% dapat dilihat pada tabel 6.

Tabel 6. Hasil Analisis Kadar Katekin

\begin{tabular}{|c|c|c|}
\hline $\begin{array}{c}\text { Jenis } \\
\text { Contoh }\end{array}$ & $\begin{array}{c}\text { Hasil } \\
\text { Pengujian/Pemeriksaan }\end{array}$ & Metode Pengujian \\
\hline $\begin{array}{c}\text { White } \\
\text { chocolate } \\
\text { yang } \\
\text { diperkaya }\end{array}$ & & \\
$\begin{array}{c}\text { Black Tea } \\
\text { Powder }\end{array}$ & $9,02 \%$ & Spektrofotometri \\
\hline
\end{tabular}

Hasil penelitian menunjukkan bahwa kadar katekin pada produk white chocolate yang diperkaya black tea powder lebih tinggi dibandingkan dengan kadar katekin pada black tea powder. Hal ini menunjukkan adanya korelasi antara katekin dalam teh dengan katekin yang berasal dari lemak cokelat (cocoa butter) yang menjadi salah satu bahan utama dalam 
pembuatan produk white chocolate sebesar 5,09\% dengan kadar black tea powder dalam produk sebesar $6 \%$.

Faktor yang mempengaruhi kadar katekin adalah varietas dan klon teh, ketinggian tempat, waktu panen teh. Pucuk pertama daun teh, kandungan katekinnya lebih tinggi dibanding daun teh yang lainnya. Begitu juga waktu panen (Anjarsari, 2016).

Katekin adalah antioksidan kuat yang terkandung dalam coklat. Salah satu fungsi antioksidan adalah mencegah penuaan dini yang bisa terjadi karena polusi ataupun radiasi. Katekin juga dijumpai pada teh meski jumlahnya tidak setinggi pada coklat (Khomsan, 2017).

Sebagian besar flavanoins/polyphenol di daun teh terdiri atas katekin seperti epicatechin (EC), epigallocatechin (EGC), epicatechin gallate (ECG), dan epigallocatechin gallate (EGCG). Epicatechin (EC) dan epigallocatechin (EGC) memunculkan rasa sedikit sepat (pahit) dengan sedikit manis setelah diminum, sedangkan bentuk gallatenya (ECG dan EGCG) memunculkan rasa sepat yang kuat (Yamanishi, 1991 dalam Anjarsari, 2016). Senyawasenyawa katekin tersebut mempunyai manfaat karena sifatnya dalam meniadakan bau, sebagai antioksidan berkemampuan untuk menghambat pertumbuhan jamur, tumor, dan virus.

\section{Kadar Theaflavin}

Analisis kadar theaflavin yang dilakukan di penelitian pendahuluan bertujuan untuk mengetahui kadar theaflavin yang terkandung dalam black tea powder sehingga dapat dilakukan perbandingan kadar theaflavin pada black tea powder sebelum dan sesudah dijadikan produk white chocolate.

Tabel 7. Hasil Analisis Kadar Theaflavin

\begin{tabular}{|c|c|c|}
\hline Jenis Contoh & $\begin{array}{c}\text { Hasil } \\
\text { Pengujian/Pemeriksaan }\end{array}$ & $\begin{array}{c}\text { Metode } \\
\text { Pengujian }\end{array}$ \\
\hline $\begin{array}{c}\text { White } \\
\text { chocolate } \\
\text { yang }\end{array}$ & \\
diperkaya & & \\
Black Tea & $0,8055 \%$ & Spektrofotometri \\
Powder & & \\
\hline
\end{tabular}

Hasil penelitian utama analisis kadar theaflavin metode spektrofotometri dengan sampel terpilih yaitu kadar CBS sebesar $38 \%$ dapat dilihat pada tabel 8 .

Tabel 8. Hasil Analisis Kadar Theaflavin

\begin{tabular}{|c|c|c|}
\hline $\begin{array}{c}\text { Jenis } \\
\text { Contoh }\end{array}$ & Pengujian/Pemeriksaan & $\begin{array}{c}\text { Metode } \\
\text { Pengujian }\end{array}$ \\
\hline $\begin{array}{c}\text { Black Tea } \\
\text { Powder }\end{array}$ & $3,843 \%$ & Spektrofotometri \\
\hline
\end{tabular}

Hasil penelitian menunjukkan bahwa kadar theaflavin dalam black tea powder lebih besar dibandingkan dengan yang ada di dalam produk white chocolate. Hal tersebut disebabkan oleh sifat volatil dari theaflavin itu sendiri.
Theaflavin merupakan senyawa berwarna merah atau oranye dalam larutan dan berkontribusi terhadap kecerahan dan rasa minuman teh. Terdapat empat jenis utama theaflavin, yaitu theaflavin $(\mathrm{TF})$, theaflavin 3 galat (TF-3-G), theaflavin 3` galat (TF-3`-G), dan theaflavin 3,3`-digalat (TF-3,3`-DG).

Tabel 9. Prekursor dan Kadar Theaflavin pada Teh Hitam

\begin{tabular}{|l|c|c|}
\hline \multicolumn{1}{|c|}{ Prekursor } & Jenis Theaflavin & Kadar (\% bk) \\
\hline EC + EGC & TF & $0,2-0,3$ \\
\hline EC + EGCG & TF-3-G & $1,0-1,5$ \\
\hline ECG + EGC & TF-3`-G & $1,0-1,5$ \\
\hline ECG + EGCG & TF-3,3`-DG & $0,6-1,2$ \\
\hline
\end{tabular}

Epigalokatekin galat (EGCG) merupakan jenis polifenol yang paling banyak jumlahnya pada teh, yaitu 20-130 mg EGCG per cup teh hijau. Selain itu pada teh hitam terdapat pigmen theaflavin dan thearubigin. Keduanya merupakan senyawa golongan polifenol yang dihasilkan selama fermentasi dan berperan dalam pembentukan warna khas teh hitam serta termasuk dalam senyawa bioaktif karena dilaporkan memiliki efek bagi kesehatan (Daniells, 2008 dalam Yahya, 2012).

Efek antioksidan theaflavin yang tinggi disebabkan kandungan gugus hidroksi $(\mathrm{OH})$ yang banyak pada theaflavin. (Leborgne, dkk. 2005 dalam Yahya, 2012). Gugus hidroksi ini memiliki aktivitas antioksidan dengan menagkap radikal bebas dan mencegah terjadinya oksidasi lipid. Selain itu, theaflavin dapat meningkatkan antioksidan alami yang terdapat dalam tubuh, seperti glutathione-S transferase (GST), glutanthione peroksidase (GPX), dismutase superperoksida (SOD), dan katalase (CAT) yang mampu menurunkan oksidasi lipid (Astuti, 2009 dalam Yahya, 2012).

\section{Respon Fisik \\ Titik Leleh}

Titik leleh dari cokelat merupakan parameter yang penting dalam menentukan kualitas cokelat, dimana cokelat yang baik yaitu cokelat yang tidak mudah meleleh di suhu ruang, namun dapat cepat meleleh di suhu tubuh.

Analisis titik leleh dilakukan untuk mengetahui suhu leleh dari produk white chocolate dengan konsentrasi CBS sebesar 38\%, 40\%, dan 42\%, sehingga dapat diketahui korelasinya dengan black tea powder. Hasil analisis dapat dilihat pada tabel 9.

Tabel 9. Hasil Analisis Titik Leleh

\begin{tabular}{|c|c|}
\hline Konsentrasi & Titik Leleh $\left({ }^{\circ} \mathrm{C}\right)$ \\
\hline Control & 36 \\
\hline $38 \%$ & 39,5 \\
\hline $40 \%$ & 41 \\
\hline $42 \%$ & 42 \\
\hline
\end{tabular}




\section{Titik Leleh White Chocolate yang Diperkaya Black Tea Powder}

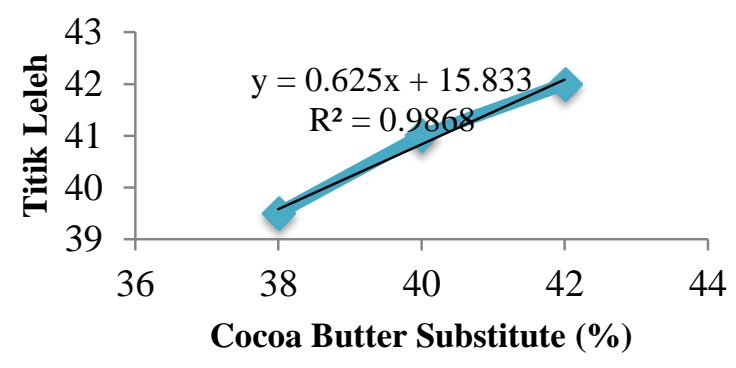

Gambar 2. Grafik Titik Leleh White Chocolate yang diperkaya Black Tea Powder

CBS akan mempengaruhi titik leleh dari cokelat yang berdampak pada tekstur cokelat yang dihasilkan. CBS pada pembuatan cokelat digunakan sebagai pelapis dan penggumpal. CBS dapat berfungsi secara maksimal pada proses tempering dan pendinginan. Apabila gagal dalam proses pendinginan dan tempering maka tekstur dari cokelat tersebut akan menjadi kurang baik (Minifie, 1989 dalam Nabila, 2017).

\section{Kekerasan (Firmness)}

Analisis kekerasan (Firmness) dilakukan untuk mengetahui tingkat kekerasan yang dapat dirasakan oleh mulut menggunakan alat texture analyzer dari produk white chocolate dengan konsentrasi CBS sebesar 38\%, 40\%, dan 42\%, sehingga dapat diketahui korelasinya dengan black tea powder. Hasil analisis dapat dilihat pada tabel 10.

Tabel 10. Hasil Analisis Kekerasan (Firmness) Metode Texture Analyzer

\begin{tabular}{|c|c|}
\hline Konsentrasi & Firmness (gForce) \\
\hline Control & 5481,36 \\
\hline $38 \%$ & 3845,36 \\
\hline $40 \%$ & 5523,41 \\
\hline $42 \%$ & 5389,19 \\
\hline
\end{tabular}

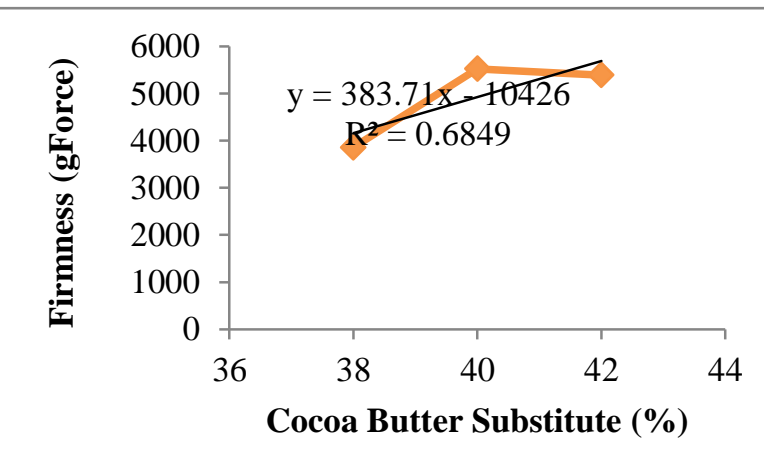

Gambar 3. Grafik Tingkat Kekerasan White Chocolate yang Diperkaya Black Tea Powder

Berdasarkan grafik di atas, menunjukkan bahwa semakin tinggi kadar CBS, maka kekerasan cokelat semakin tinggi. Hal tersebut sesuai dengan hasil penelitian Permatasari (2016) yang menyatakan bahwa, penggunaan jenis lemak nabati mempengaruhi pula terhadap kekerasan. Cokelat memiliki kekerasan paling lunak adalah cokelat dengan penambahan margarin, sementara cokelat yang memiliki kekerasan paling tinggi adalah cokelat dengan penambahan cocoa butter dan diikuti dengan vegetable shortening.

Sama halnya dengan titik leleh, kekerasan cokelat juga dipengaruhi oleh asam lemak penyusunnya serta karakteristik dari kristal lemak. Menurunnya kekerasan produk cokelat karena inkompabilitas lemak terjadi melalui pembentukan kisi-kisi kristal yang tidak sempurna yang dapat meningkatkan mobilitas pergerakan molekul, perubahan di dalam struktur polimorfis serta perubahan di dalam kecepatan kristalisasi (Lanning, 1981 dan Hogenbrik 1984 dalam Permatasari 2016).

\section{Respon Organoleptik} Warna

Hasil uji hedonik untuk atribut warna pada produk white chocolate dengan konsentrasi cocoa butter substitute sebesar 38\%, 40\%, dan $42 \%$ dapat dilihat pada tabel 11 .

Tabel 11. Hasil Uji Organoleptik Metode Hedonik Atribut Warna

\begin{tabular}{|c|c|}
\hline Konsentrasi & Rata-Rata \\
\hline $38 \%$ & 4,6 \\
\hline $40 \%$ & 4,4 \\
\hline $42 \%$ & 4,3 \\
\hline
\end{tabular}

Hasil pengujian organoleptik metode hedonik terhadap atribut warna memiliki nilai rata-rata secara keseluruhan sebesar 4,45. Hal ini menunjukkan bahwa panelis memberikan respon suka terhadap produk white chocolate atribut warna.

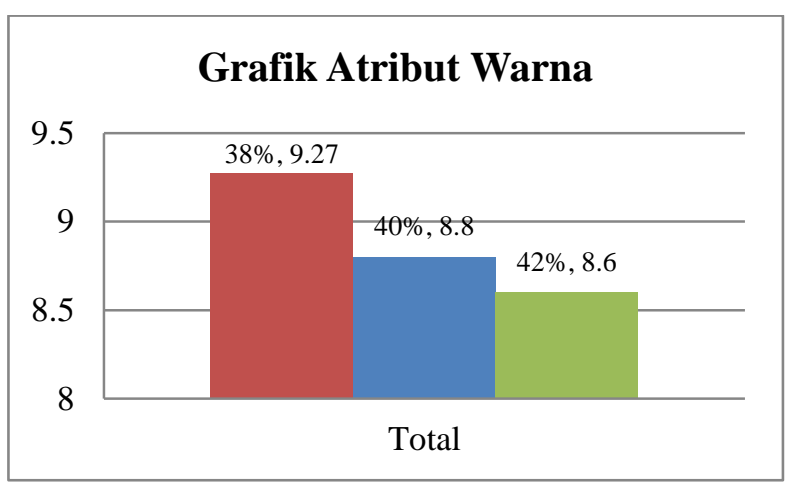

Gambar 4. Grafik Uji Hedonik Atribut Warna

Berdasarkan hasil pengujian organoleptik atribut warna, maka produk white chocolate dengan penambahan black tea powder yang paling disukai oleh panelis dengan rata-rata tertinggi yaitu produk dengan konsentrasi Cocoa Butter Substitute (CBS) sebesar $38 \%$.

Produk white chocolate dengan konsesntrasi CBS $38 \%$ memiliki kenampakan warna coklat 
kehitaman. Warna hitam berasal dari black tea powder yang memiliki kenampakan warna cokelat kehitaman. Menurut Rukmana (2015), Warna dari black tea powder berasal dari proses pengeringan yang membuat daun menjadi gelap sehingga terjadi pemecahan unsur klorofil dan terlepasnya unsur tanin.

Menurut Desrosier (2008) dalam Fitriany (2016), bahan pangan yang mengalami pengolahan atau pemanasan dapat diduga mengalami perubahan yang nyata dalam warna bahan pangan. Proses pemanasan, pembekuan, atau pengeringan makanan mengubah kualitas fisik dan kimianya.

\section{Aroma}

Hasil uji hedonik untuk atribut aroma pada produk white chocolate dengan konsentrasi cocoa butter substitute sebesar 38\%, $40 \%$, dan $42 \%$ dapat dilihat pada tabel 12 .

Tabel 12. Hasil Uji Organoleptik Metode Hedonik Atribut Aroma

\begin{tabular}{|c|c|}
\hline Konsentrasi & Rata-Rata \\
\hline $38 \%$ & 4,265 \\
\hline $40 \%$ & 3,97 \\
\hline $42 \%$ & 4,165 \\
\hline
\end{tabular}

Hasil pengujian organoleptik metode hedonik terhadap atribut aroma memiliki nilai rata-rata secara keseluruhan sebesar 4,133. Hal ini menunjukkan bahwa panelis memberikan respon agak suka terhadap produk white chocolate atribut aroma.

Berdasarkan hasil pengujian organoleptik atribut aroma, maka produk white chocolate dengan penambahan black tea powder yang paling disukai oleh panelis dengan rata-rata tertinggi yaitu produk dengan konsentasi Cocoa Butter Substitute (CBS) sebesar $38 \%$.

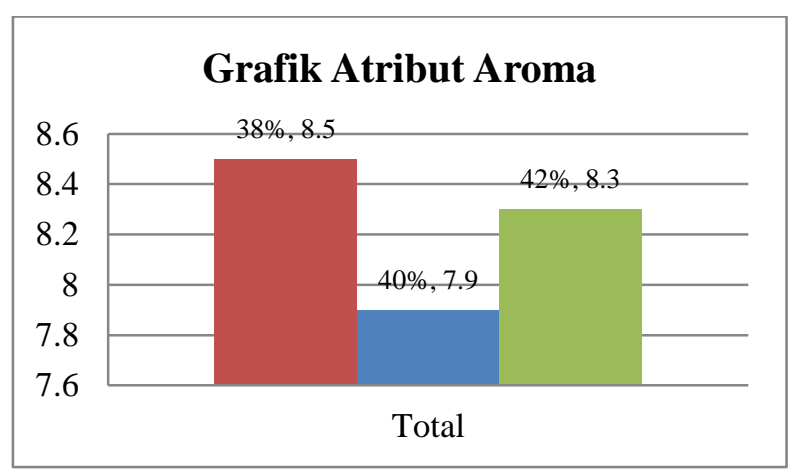

Gambar 5. Grafik Uji Hedonik Atribut Aroma

Aroma produk white chocolate dengan konsentrasi CBS 38\% berasal dari substansi aromatis black tea powder. Timbulnya aroma ini secara langsung atau tidak langsung selalu dihubungkan dengan terjadinya oksidasi senyawa polifenol. Aroma berasal dari glikosida yang terurai menjadi gula sederhana dan senyawa beraroma. Timbulnya aroma adalah akibat penguraian protein. Asam amino bersama dengan karbohidrat dan katekin akan membentuk senyawa aromatis. Asam amino yang paling berpengaruh adalah alanin, fenilalanin, valin, leusin, dan isoleusin. Adanya minyak esensial yang mudah menguap juga disebut sebagai sumber aroma teh (Rukmana, 2015).

Menurut Kusumawati (1999) dalam Mayasari (2002), Aroma yang timbul pada produk cokelat batang dapat disebabkan dari proses pemanasan. Dimana dari proses pemanasan inilah ditujukan untuk meningkatkan aroma khasa cokelat batang, dan juga dapat menghilangkan bau-bau yang tidak dikehendaki.

Menurut Ketaren (1986) dalam Mayasari (2002), Penyebab timbulnya aroma dari proses pemasakan, dapat disebabkan karena penambahan zatzat penambah cita rasa dan aroma, seperti cokelat bubuk dengan penambahan gula akan lebih meningkatkan aroma khas cokelat. Demikian pula penambahan lemak cokelat, mentega, dan susu akan memberikan aroma yang lebih baik, dimana akibat pencampuran zat-zat penambah tersebut akan terbentuk hasil penguraian laktosa dalam lemak susu oleh aktivitas mikroorganisme, sehingga akan dihasilkan cokelat batang dengan aroma yang disenangi, sedangkan semakin lama waktu pemasakan akan mengurangi aroma cokelat batang yang dihasilkan.

\section{Rasa}

Penelitian Mayasari (2002), Salah satu faktor yang berpengaruh dalam menentukan mutu bahan pangan adalah rasa dalam bahan pangan. Rasa dalam bahan pangan dapat berasal dari sifat bahan itu sendiri atau adanya zat penambah cita rasa pada proses pengolahan, sehingga menyebabkan rasa yang lebih baik. Batasan dari rasa terhadap suatu produk pangan dapat dirasakan. Hal ini disebabkan karena setiap orang untuk kondisi sampel yang sama memiliki tingkat kesukaan terhadap suatu produk berbeda-beda, sehingga dapat menimbulkan perbedaan nilai atau tingkatan rasa pada produk pangan.

Hasil uji hedonik untuk atribut rasa pada produk white chocolate dengan konsentrasi cocoa butter substitute sebesar $38 \%, 40 \%$, dan $42 \%$ dapat dilihat pada tabel 13.

Tabel 13. Hasil Uji Organoleptik Metode Hedonik Atribut Rasa

\begin{tabular}{|c|c|}
\hline Konsentrasi & Rata-Rata \\
\hline $38 \%$ & 4,665 \\
\hline $40 \%$ & 4,65 \\
\hline $42 \%$ & 4,72 \\
\hline
\end{tabular}

Hasil pengujian organoleptik metode hedonik terhadap atribut rasa memiliki nilai rata-rata secara keseluruhan sebesar 4,67. Hal ini menunjukkan bahwa panelis memberikan respon agak suka terhadap produk white chocolate atribut rasa. 


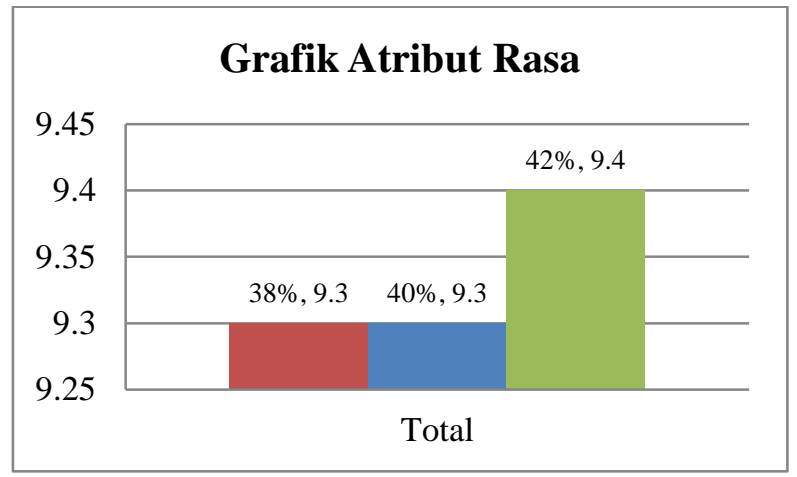

Gambar 6. Grafik Uji Hedonik Atribut Rasa

Berdasarkan hasil pengujian organoleptik atribut rasa, maka produk white chocolate dengan penambahan black tea powder yang paling disukai oleh panelis dengan rata-rata tertinggi yaitu produk dengan konsentasi Cocoa Butter Substitute (CBS) sebesar $42 \%$.

Rasa pada produk cokelat dengan rata-rata tertinggi memiliki konsentrasi black tea powder paling sedikit, yaitu sekitar $2 \%$. Hal tersebut dapat menjadi pengaruh terhadap sifat organoleptik terhadap atribut rasa. Rasa pahit dari produk white chocolate berasal dari black tea powder yang memiliki kandungan katekin.

Katekin berperan penting di dalam menentukan aroma dan rasa. Katekin merupakan senyawa tidak berwarna dan larut dalam air serta membawa sifat pahit dan sepat pada seduhan teh. Senyawa ini paling penting dalam daun teh karena menentukan kualitas teh dalam pengolahannya (Anjarsari, 2016).

Penelitian Mayasari (2007), Rasa manis ditimbulkan oleh senyawa organik alifatik yang mengandung gugus $\mathrm{OH}$ seperti alkohol, asam amino, aldehida, dan gliserol. Hal tersebut sesuai dengan penelitian ini, dimana rasa pada cokelat batang diakibatkan dari penambahan gula tepung, sehingga memberikan rasa manis.

Menurut Ketaren (1986) dalam Mayasari (2007), Rasa dominan yang timbul dari produk cokelat adalah rasa cokelat yang khas, rasa cokelat yang khas pada produk yang paling disukai adalah produk dengan sumber lemak cocoa butter dan vegetable shortening. Hal ini dikarenakan cocoa butter memiliki rasa cokelat yang khas sehingga menjadikan produk akhir memiliki rasa khas cokelat yang lebih kuat, kemudian rasa dari vegetable shortening adalah plain, sehingga tidak mengganggu rasa dari produk akhir cokelat dan penerimaan panelis terhadap produk cokelat. Produk cokelat yang menggunakan vegetable shortening tidak memiliki perbedaan signifikan dengan produk cokelat dengan menggunakan cocoa butter.

Menurut Saleh (2005) dalam Permatasari (2016), Untuk menghasilkan rasa yang lebih baik selain penambahan dari bahan-bahan yang digunakan juga diperlukan suatu proses pencampuran yang baik, dimana pada proses pencampuran tersebut meliputi proses pemanasan dan proses penghancuran. Pada pembuatan produk cokelat proses pencampuran ini disebut proses conching.

\section{Tekstur}

Menurut Soekarto (1985) dalam Mayasari (2007), Tekstur adalah suatu sifat bahan atau produk yang dapat dirasakan melalui sentuhan kulit atau pencicipan. Penginderaan terhadap tekstur yang berasal dari sentuhan dapat ditangkap oleh seluruh permukaan kulit. Tetapi biasanya seseorang ingin menilai tekstur suatu bahan maka digunakan ujung jari tangan. Tekstur suatu produk mempengaruhi mutu produk yang dihasilkan dan merupakan salah satu indikasi dari kerusakan produk.

Hasil uji hedonik untuk atribut tekstur pada produk white chocolate dengan konsentrasi cocoa butter substitute sebesar $38 \%$, $40 \%$, dan $42 \%$ dapat dilihat pada tabel 14 .

Tabel 14. Hasil Uji Organoleptik Metode Hedonik Atribut Tekstur

\begin{tabular}{|c|c|}
\hline Konsentrasi & Rata-Rata \\
\hline $38 \%$ & 3,935 \\
\hline $40 \%$ & 4,25 \\
\hline $42 \%$ & 4,35 \\
\hline
\end{tabular}

Hasil pengujian organoleptik metode hedonik terhadap atribut tekstur memiliki nilai rata-rata secara keseluruhan sebesar 4,17. Hal ini menunjukkan bahwa panelis memberikan respon agak suka terhadap produk white chocolate atribut tekstur.

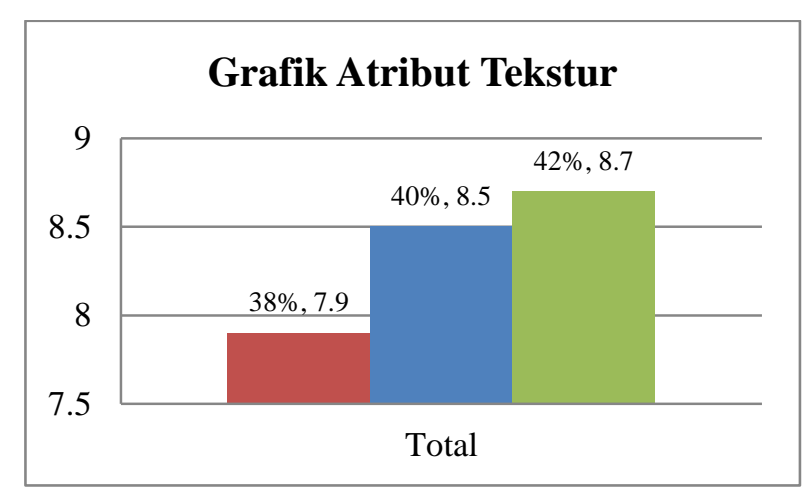

Gambar 7. Grafik Uji Hedonik Atribut Tekstur

Berdasarkan hasil pengujian organoleptik atribut tekstur, maka produk white chocolate dengan penambahan black tea powder yang paling disukai oleh panelis dengan rata-rata tertinggi yaitu produk dengan konsentasi Cocoa Butter Substitute (CBS) sebesar $42 \%$.

Tekstur produk white chocolate dengan konsentasi Cocoa Butter Substitute (CBS) sebesar $42 \%$ dipengaruhi oleh suhu dan lama penyimpanan. CBS memiliki tingkat kekerasan yang lebih tinggi dibandingkan dengan cocoa butter. Pencampuran antara CBS dengan cocoa butter yang diperkaya black tea powder mengakibatkan tekstur menjadi keras, 
sehingga tidak mudah meleleh. Hal tersebut sesuai dengan hasil penelitian Nabila (2016) yang menyatakan bahwa, semakin tinggi konsentrasi CBS yang ditambahkan maka tingkat kesukaan panelis semakin tinggi karena tekstur white chocolate akan lebih lama meleleh dan tidak mudah mencair pada suhu ruang. Semakin rendah konsentrasi CBS yang digunakan maka kesukaan panelis semakin menurun karena tekstur yang dihasilkan lebih mudah lunak dan meleleh.

Menurut Minifie (1989) dalam Nabila (2016), Hal tersebut dikarenakan penambahan CBS akan mempengaruhi titik leleh dari cokelat yang berdampak pada tekstur cokelat yang dihasilkan. CBS pada pembuatan cokelat digunakan sebagai pelapis dan penggumpal. CBS dapat berfungsi secara maksimal pada proses tempering dan pendinginan. Apabila gagal dalam proses pendinginan dan tempering maka tekstur dari cokelat tersebut akan menjadi kurang baik.

Menurut Buckle (1987) dalam Mayasari (2007), penambahan sukrosa atau gula tepung juga dapat mempengaruhi dalam penampakan produk pangan, seperti cokelat batang. Selain memberikan rasa manis, penambahan gula dengan campuran bahan berlemak akan memberikan tekstur yang baik, dan tidak rapuh. Hal ini akan menyebabkan penampakan produk cokelat batang yang lebih baik.

Menurut Prasetya (2009) dalam Noordiansyah (2016), Cokelat yang baik harus memiliki tekstur yang halus (smooth and buttery) yang bisa meleleh dengan lembut dan perlahan di dalam mulut dengan cita rasa yang kompleks dan menyenangkan. Cokelat harus dapat meleleh dalam mulut, yakni ketika dimakan tanpa perlu meninggalkan kesan keras. Tekstur seperti lilin (waxy mouth feel) menandakan bahwa cokelat mengandung sejumlah lemak. Cokelat merupakan dispersi partikel partikel dari bubuk cokelat dan gula di dalam suatu fase cair lemak kakao. Pada suhu kamar partikel-partikel tersebut disekat oleh kristal-kristal lemak yang bertindak sebagai semen perekat. Oleh karena itu sifat-sifat fisik dan sensori cokelat langsung berhubungan dengan kristalisasi lemak kakao.

\section{Aftertaste}

Aftertaste adalah sensasi makanan setelah dikonsumsi dimana ada kesan yang dirasakan setelah penginderaan selesai dilakukan (Widiantoko, 2014).

Hasil uji hedonik untuk atribut aftertaste pada produk white chocolate dengan konsentrasi cocoa butter substitute sebesar 38\%, $40 \%$, dan $42 \%$ dapat dilihat pada tabel 15 .

Tabel 15. Hasil Uji Organoleptik Metode Hedonik Atribut Aftertaste

\begin{tabular}{|l|l|}
\hline Konsentrasi & Rata-Rata \\
\hline $38 \%$ & 4,465 \\
\hline $40 \%$ & 4,33 \\
\hline $42 \%$ & 4,335 \\
\hline
\end{tabular}

Hasil pengujian organoleptik metode hedonik terhadap atribut aftertaste memiliki nilai rata-rata secara keseluruhan sebesar 4,38. Hal ini menunjukkan bahwa panelis memberikan respon agak suka terhadap produk white chocolate atribut aftertaste.

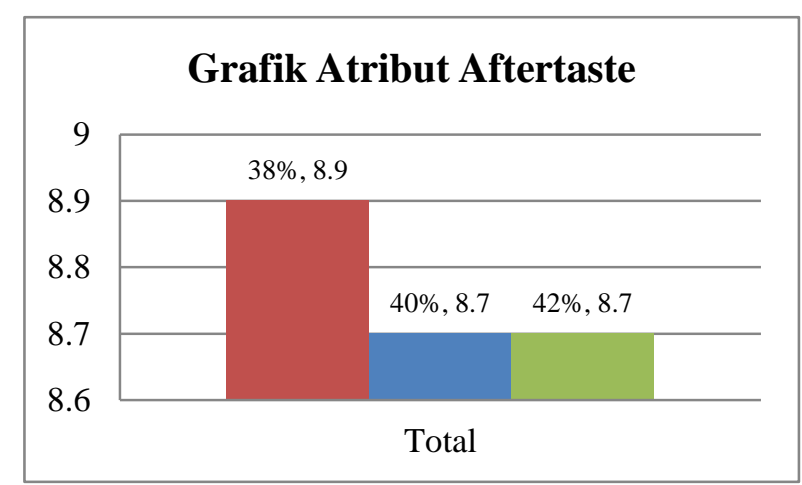

Gambar 8. Grafik Uji Hedonik Atribut Aftertaste

Berdasarkan hasil pengujian organoleptik atribut aftertaste, maka produk white chocolate dengan penambahan black tea powder yang paling disukai oleh panelis dengan rata-rata tertinggi yaitu produk dengan konsentasi Cocoa Butter Substitute (CBS) sebesar $38 \%$.

Aftertaste yang dihasilkan dari produk white chocolate ini berasal dari black tea powder, sedangkan CBS tidak berpengaruh dalam hal aftertaste. Hal tersebut sesuai dengan penelitian Nabila (2017) yang menyatakan bahwa, CBS tidak memberikan pengaruh yang nyata terhadap atribut aftertaste white chocolate, hal ini disebabkan CBS memiliki rasa yang tawar atau tidak berasa. CBS juga merupakan lemak nabati pengganti lemak coklat yang tidak memberikan sensasi lilin (no waxy aftertaste) sehingga CBS tidak berpengaruh dalam hal aftertaste.

Aftertaste sepat berasal dari tanin yang terkandung dalam black tea powder. Tanin dalam teh merupakan tanin yang tidak dapat dihidrolisis atau tanin terkondensasi. Tanin tersebut mempunyai sifat larut dalam air, alkohol, gliserin, aseton, tidak larut dalam eter, benzene, terasa sepat, berwarna kuning, amorf, ringan, dan tidak berbau (Rukmana, 2015).

Berdasarkan hasil penelitian yang telah dilakukan, maka diperoleh kesimpulan sebagai berikut :

1. Konsentrasi cocoa butter substitute (CBS) berkorelasi positif dengan black tea powder terhadap karakteristik titik leleh dan kekerasan white chocolate.

2. Adanya interaksi antara cocoa butter substitute (CBS) dengan black tea powder terhadap respon organoleptik (warna, aroma, rasa, tekstur, dan aftertaste), respon kimia (lemak, asam lemak, katekin, dan theaflavin) serta respon fisik (titik leleh dan kekerasan).

3. Pemilihan sampel terpilih dari pengujian secara organoleptik metode hedonik dengan atribut warna, 
aroma, rasa, tekstur, dan aftertaste sehingga didapatkan produk white chocolate dengan konsentrasi CBS 38\%.

4. Sampel terpilih memiliki kadar lemak total sebesar $43,4 \%$, asam palmitat sebesar $17,70 \%$, kadar katekin sebesar $9,02 \%$, dan theaflavin sebesar $0,8055 \%$, titik leleh sebesar $39,5^{\circ} \mathrm{C}$, dan kekerasan sebesar 3854,36 gF.

\section{Daftar Pustaka}

1. Anjarsari, I.R.D. (2016). Jurnal Kultivasi Vol 15 (2) : Katekin Teh Indonesia : Prospek dan Manfaatnya. Department of Crop Science, Universitas Padjajaran.

2. Atkinson, C., M.Banks, C.France, \& C.McFadden. (2010). The chocolate and coffee bible. London: Anness Publishing Ltd.

3. Ekawati. 2007. Pengaruh Teh Hitam (Camellia sinensis (L.)O.K.) Terhadap Ketebalan Dinding Arteri Koronaria Tikus Putih (Rattus norvegicus) yang Diberi Diet Tinggi Lemak. PKMI, Fakultas Kedokteran Universitas Gadjah Mada,Yogyakarta.. ..

4. Kurniatri, A., Arifayu, dkk. 2015. Formulasi Tablet Salut Selaput Katekin dari Ekstrak Gambir (Uncaria gambir Roxb.). Volume : 5. Pusat Biomedis dan Teknologi Dasar Kesehatan, Badan Penelitian dan Pengembangan Kesehatan, Kementerian Kesehatan, Indonesia.

5. Mayasari, P.D. 2007. Pengaruh Penambahan Lemak Coklat dan Lesitin Terhadap Sifat Organoleptik Produk Coklat Batang, Program Studi Teknologi Pangan, Fakultas Teknik, Universitas Pasundan Bandung.
6. Nabila, Y.S. 2017. Perbandingan Susu Skin dengan Tepung Kedelai dan Konsentrasi Cocoa Butter Substitute terhadap Karakteristik White Chocolate. Program Studi Teknologi Pangan, Fakultas Teknik, Universitas Pasundan Bandung.

7. Noordiansyah. 2016. Peningkatan Karakteristik Olahan Cokelat yang Dipengaruhi Penambahan Cocoa Butter Substitute dan Tepung Kacang Koro (Canavalia Ensiformi L). Program Studi Teknologi Pangan, Fakultas Teknik, Universitas Pasundan Bandung.

8. Permatasari, N. 2016. Karakteistik Cokelat Filling Kacang Mete yang Dipengaruhi Jenis dan Jumlah Lemak Nabati. Program Studi Teknologi Pangan, Fakultas Teknik, Universitas Pasundan Bandung.

9. Turminah, S. 2009. Efek Asam Lemak Jenuh dan Asam Lemak Tak Jenuh "Trans" terhadap Kesehatan. Media Peneliti dan Pengembangan Kesehatan. Volume XIX Tahun 2009, Suplemen II. 